\title{
Pengaruh Daya Tarik Pesan Iklan Layanan Masyarakat \\ di Youtube dan Tingkat Pengetahuan Masyarakat Terhadap Keputusan Menggunakan Vaksin Measles dan Rubella (Mr) pada Anak (Studi Eksplanatif pada Subscribe Iklan Layanan Masyarakat Vaksin Measles dan Rubella Versi Panjang)
}

\author{
Ilona Vicenovie Oisina ${ }^{1}$, Ivonne Ruth Vitamaya Oishi ${ }^{2}$ \\ ${ }^{1}$ UPI YAI, Jakarta, ${ }^{2}$ Universitas Methodist Indonesia, Medan \\ e-mail: ${ }^{1}$ ilonaoisina@yahoo.com, ${ }^{2}$ ivonneruthsitumeang@gmail.com
}

\begin{abstract}
Abstrak
Media sosial merupakan sasaran pembuat iklan untuk mengiklankan berbagai produk dan layanan. Sama halnya dengan iklan layanan masyarakat menggunakan media sosial untuk beriklan. Media sosial yang dipilih beragam tergantung kebutuhan. Iklan layanan masyarakat tentang vaksin MR terdapat di berbagai media sosial salah satunya di media Youtube, dengan banyak versi. Dalam penelitian ini mengambil iklan layanan masyarakat tentang vaksin MR versi panjang. Diharapkan dengan iklan layanan masyarakat dapat memberikan pengetahuan bagi pengguna agar mengetahui bahwa vaksin MR penting bagi perkembangan anak, dan tidak bertentangan dengan agama apapun. Penelitian ini menggunakan teori Computer Mediated Communication. Paradigma yang digunakan positivisme dengan pendekatan kuantitatif, sifat penelitian eksplanatif dan metode penelitian survei. Populasi nya adalah subscribe iklan layanan masyarakat sebanyak 2146 per januari 2018 dengan sampel penelitian sebanyak 96 respondn yang diambil dengan purposive sampling. Hasil yang diperoleh dari hubungan daya tarik iklan layanan masyarakat dan tingkat pengetahuan dengankeputusan penggunaan sebesar 0,494. Uji F hitung > F tabel yaitu 15.768 $>3.099$, dapat disimpulkan bahwa terdapat pengaruh secara simultan daya tarik iklan layanan masyarakat vaksin MR dan tingkat pengetahuan terhadap keputusan penggunaan vaksin MR.
\end{abstract}

Kata Kunci: Daya Tarik Pesan, Iklan Layanan Masyarakat, Tingkat Pengetahuan, Keputusan Penggunaan, Vaksin MR

\footnotetext{
Abstract

Social media is the target of advertisers to advertise various products and services. Similarly, public service advertisements use social media to advertise. The selected social media varies depending on needs. Public service advertisements about MR vaccines are available on various social media, one of
} 
which is on Youtube, with many versions. In this study took public service advertisements about the long version of the MR vaccine. It is expected that public service advertisements can provide knowledge for users to know that MR vaccines are important for children's development, and not contrary to any religion. This research uses the theory of Computer Mediated Communication. The paradigm used positivism with quantitative approaches, the nature of explanatory research and survey research methods. The population is to subscribe to 2146 public service advertisements as of January 2018 with a sample of 96 respondents taken using purposive sampling. The results obtained from the relationship of the attractiveness of public service advertisements and the level of knowledge with use decisions are 0.494. F count test> F table is 15,768> 3,099, it can be concluded that there is a simultan eous influence of the attraction of MR vaccine public service ads and the level of knowledge on the decision to use MR vaccine.

Keywords: Message Attractiveness, Public Service Announcements, Knowledge Stage, User Satisfaction, MR Vaccine.

\section{PENDAHULUAN}

Pengguna Internet di Indonesia setiap tahun terus bertambah, hal ini dikarenakan peningkatan kebutuhan akan media internet dalam kehidupan seharihari. Media internet memberikan banyak kemudahan bagi si pengguna. Menurut Asosiasi Penyelenggara Jasa Internet Indonesia (APJII) memaparkan hasil survei bertajuk "Penetrasi dan Perilaku Pengguna Internet Indonesia 2017". Hasil survei yang berkerja sama dengan Teknopreneur itu menyebutkan, penetrasi pengguna internet di Indonesia meningkat menjadi 143,26 juta jiwa atau setara 54,7 persen dari total populasi republik ini (Buletin APJII, 2018).

Media sosial sedang menjadi trent di masyarakat, baik masyarakat Indonesia maupun masyarakat dunia, mulai dari anak-anak sampai orang dewasa semua menggunakan media sosial sebagai sarana untuk berkomunikasi serta sarana untuk mendapatkan informasi yang bervariatif. Media sosial yang banyak digunakan antara lain Twitter, Facebook, Instagram, Pinterest, BBM, Line, dan lain-lain tergantung dari kebutuhan. Banyak orang akhirnya memilih dan menyukai media sosial dikarenakan kemudahan dalam melakukan interaksi online dengan teknologi mobile yang praktis seperti smartphone maupun iphone yang dapat di bawa ke mana-mana, sehingga dapat melakukannya dimana saja dan kapan saja mereka butuhkan. 
Berbagai media sosial yang sering digunakan oleh masyarakat di seluruh dunia, salah satunya adalah media Youtube. Youtube merupakan salah satu media sosial terpopuler di Indonesia bahkan di dunia selain Facebook dan Twitter. Situs analisis Socialbakers (2016) menunjukkan bahwa Indonesia berada di peringkat ke-4 sebagai negara pengguna Youtube di dunia (Yuniyanto dan Sirine, 2018). Penggunaan media sosial yang terus meningkat setiap tahunnya memberikan peluang bagi produsen untuk memanfaatkan media sosial dalam mempromosikn produk dan layanan mereka melalui media sosial.

Iklan layanan masyarakat dimedia sosial sangat bervariatif, salah satunya dengn menggunakan media youtube. Media youtube memiliki daya tarik bagi pengunanya untuk menambah informasi. Banyaknya vlog (video blog) dan viral video kampanye di youtube merupakan trend terbaru untuk bersosialisasi dan berbagi informasi dikalangan pengguna internet saat ini. Dari fenomena trennya vlog dan viral video kampanye di youtube menunjukan bahwa, publik lebih menyukai informasi yang disampaikan dalam bentuk visualisasi gambar dan suara daripada bentuk teks. Youtube merupakan situs jejaring video yang paling banyak memiliki jumlah viewer dan subsecribers daripada situs lain, sehingga video yang di upload pada situs youtube akan lebih cepat menjadi viral ketimbang melalui situs lain (Cahyono, Budiarjo, Hidayat, 2016).

Walau dalam perkembangannya media YouTube tidak lagi hanya digunakan sebagai media untuk mengunggah dan membagikan video-video pribadi kepada rekan-rekan terdekat saja, tetapi lebih dari itu masuk pada tahap adaptasi penggunaan berbagai media sosial termasuk media YouTube. Melalui para pengguna media YouTube dapat dijadikan sarana untuk pengumpulan berbagai informasi yang dibutuhkan, sehingga banyak iklan-iklan komersil dan iklan layanan masyarakat juga mengambil kesempatan untuk mengunggah iklan mereka dimedia youtube. Dalam penelitian ini penulis meneliti iklan layanan masyarakat tentang vaksin Measles dan Rubella (MR) yang disampaikan melalui YouTube. Iklan layanan masyarakat ini diharapkan dapat ditonton oleh si pengguna saat mereka sedang menggunakan online di media youtube sehingga 
pengguna menjadi mendapatkan informasi tentang kegunaan menggunakan vaksin MR maupun dampak yang ditimbulkan jika tidak menggunakan vaksin MR.

Daya tarik iklan juga mengacu pada pendekatan kreatif pesan yang digunakan untuk dapat menarik perhatian pengguna media Youtube, dengan menonton diharapkan mendapatkan informasi serta dapat mempengaruhi perasaan pengguna terhadap pesan yang disampaikan sehingga dapat tertarik untuk menggunakan vaksin MR. Untuk menghasilkan iklan yang efektif, diperlukan daya tarik dan strategi kreatif iklan yang tepat sesuai dengan tujuan yang akan dicapai. Menyadari penting pesan dalam iklan layanan masyarakat tersebutpenyampaian pesan dilakukan diberbagai media komunikasi terutama media Youtube, hal ini dilkukan untuk pemberian informasi kepada masyaraskat mengenai pentingnya memberikan vaksin MR ke anak hingga usia 15 tahun. Informasi yang ingin disampaikan harus menjadi viral di masyarakat, hal ini menunjukkan adanya perhatian dari pengguna media.

Dalam penelitian ini penulis ingin meneliti tentang daya tarik iklan layanan masyarakat dan pengetahuan masyarakat tentang vaksin MR terhadap keputusan menggunakan vaksin MR ke anaknya. Fenomena yang terjadi di masyarakat menunjukkan bahwa banyak pihak yang pro dan kontra terhadap vaksin MR tersebut sehingga Kementerian Kesehatan berupaya terus melakukan berbagai kampanye, sosialisasi dan iklan layanan masyarakat diberbagai media cetak, elektronik dan media online dengan tujuan agar masyarakat mendapatkan informasi yang tepat tentang vaksin MR tersebut langsung dari ahlinya. Iklan layanan masyarakat tentang vaksin MR memiliki banyak versi ada yang berdurasi panjang dan pendek. Namun isi pesan dalam iklan layanan masyarakat tersebut disampaikan oleh dokter yang dianggap kredibel dalam menyampaikan pesan ini. Diharapkan dengan kreatif seperti ini pesan iklan ini dapat diterima dengan baik oleh si pengguna Youtube.

Yang menjadi perumusan masalah dalam penelitian ini adalah:

a. Seberapa besar pengaruh daya tarik iklan layanan masyarakat di Youtube terhadap keputusan menggunakan vaksin Measles dan Rubella (MR)? (Studi ekplanatif pada subscribe iklan layanan masyarakat di Youtube). 
b. Seberapa besar pengaruh tingkat pengetahuan masyarakat terhadap keputusan menggunakan vaksin Measles dan Rubella (MR)? (Studi ekplanatif pada subscribe iklan layanan masyarakat di Youtube).

c. Seberapa besar pengaruh daya tarik iklan layanan masyarakat di Youtube dan tingkat pengetahuan masyarakat terhadap keputusan menggunakan vaksin Measles dan Rubella (MR)? (Studi ekplanatif pada subscribe iklan layanan masyarakat di Youtube).

Penelitian ini menggunakan paradigma positivistik, dimana paradigma ini dilandasi pada suatu asumsi bahwa suatu gejala itu dapat diklasifikasikan, dan hubungan gejala bersifat kausal (sebab akibat), maka peneliti dapat melakukan penelitian dengan memfokuskan kepada beberapa variabel saja Sugiyono (2015).

Pendekatan yang digunakan kuantitatif. Pendekatan kuantitatif yang bertujuan untuk mencari kebenaran secara objektif, empiris, sistematis dan terorganisir. Karena penelitian ini kuantitatif bersifat konkret yang dapat dikuantitaskan berupa angka, sehingga penelitian ini bersifat objektif yang hasilnya dapat digeneralisasikan terhadap populasi dan bisa ditafsirkan oleh semua orang. Penelitian kuantitatif adalah penelitian yang menggambarkan atau menjelaskan suatu masalah yang hasilnya dapat digeneralisasikan. Dengan demikian penelitian kuantitatif tidak perlu mementingkan kedalaman data hasil riset dianggap merupakan resresentasi dari seluruh populasi. (Kriyantono, 2012).

Jenis penelitian yang digunakan eksplanatif. Peneliti mementingkan aspek keluasan data sehingga data atau hasil riset dianggap merupakan represetasi dari seluruh populasi. Peneliti dituntut bersikap objektif dan memisahkan diri dari data. Semua harus objektif dengan diuji dahulu apakah batasan konsep dan alat ukurnya sudah memenuhi prinsip reliabilitas dan validitas. Peneliti berusaha membatasi konsep dan variabel yang diteliti dengan mengarahkan riset dalam setting yang terkontrol, lebih sistematik dan terstruktur. (Krisyantono, 2012).

Metode penelitian ini survei. Survei adalah metode riset dengan menggunakan kuesioner sebagai instrumen pengumpulan datanya. Tujuannya untuk memperoleh informasi tentang sejumlah responden yang dianggap mewakili populasi tertentu (Kriyantono, 2012).

\section{PEMBAHASAN}

\section{Populasi}

Populasi merupakan wilayah generalilasi yang terdiri atas obyek atau subyek yang memiliki kualitas dan karakteristik tertentu yang ditetapkan oleh peneliti untuk dipelajari dan kemudian ditarik kesimpulannya. Populasi bukan 
hanya sekedar jumlah, namun meliputi juga seluruh karakteristiknya atau sifat yang dimiliki oleh obyek atau subyek itu (Sugiyono, 2015).

Adapun populasi untuk subscribe Iklan Layanan Masyarakat Vaksinasi MR per Januari 2018 sejumlah: 2146 responden.

\section{Sampel}

Untuk menentukan ukuran sampel dari populasi yang sudah diketahui jumlahnya, penelitian ini diukur dengan menggunakan rumus Slovin (Kriyantono, 2010) yaitu:

$$
n=\frac{N}{N d^{2}+1}
$$

\section{Keterangan :}

$\mathrm{n}=\quad$ Jumlah sampel yang dicari.

$\mathrm{N}=\quad$ Jumlah populasi

$\mathrm{d}=\quad$ level signifikansi yang diinginkan (umumnya 0,05 untuk bidang noneksak dan 0,01 untuk bidang eksakta).

$$
\begin{aligned}
\mathrm{n} & =\frac{2146}{2146(0.10)^{2}+1} \\
\mathrm{n} & =\frac{2146}{2146(0.01)+1} \\
& =95,55
\end{aligned}
$$

Jadi hasilnya 95,55, dibulatkan menjadi 96 sampel. 


\section{Teknik Penarikan Sampel}

Pengambilan sampel dilakukan dengan jenis teknik penarikan sampel pada penelitian ini menggunakan teknik Purposive Sampling. Sugiyono (2008) menyatakan bahwa sampling purposive adalah teknik penentuan sampel dengan pertimbangan tertentu. Menurut Margono (2004), pemilihan sekelompok subjek dalam purposive sampling didasarkan atas ciri-ciri tertentu yang dipandang mempunyai sangkut paut yang erat dengan ciri-ciri populasi yang sudah diketahui sebelumnya, dengan kata lain unit sampel yang dihubungi disesuaikan dengan kriteria-kriteria tertentu yang diterapkan berdasarkan tujuan penelitian.

Adapun kriteria yang ditentukan oleh peneliti antara lain:

1. Subscribe iklan layanan masyarakat di Youtube.

2. Sudah pernah menonton iklan layanan masyarakat vaksin MR.

3. Memberikan komentar pada iklan layanan masyarakat terserbut.

4. Memberikan vaksin MR ke anaknya.

\section{Hasil Uji Validitas dan Reliabilitas}

Berikut ini hasil perhitungan menggunakan program SPSS 20 terhadap data hasil jawaban responden pada uji validitas terhadap 30 responden sebagai sampel. Uji signifikansi dilakukan dengan membandingkan nilai $r$ hitung dengan $\mathrm{r}$ tabel. Nilai $\mathrm{r}$ tabel dapat dicari, dimana degree of freedom $(\mathrm{df})=\mathrm{n}-2$, dalam hal ini $\mathrm{n}$ adalah jumlah sampel.

$\mathrm{R}$ tabel $=30$ (jumlah sampel) $-2=28$ dengan alpha 0,05 dan dicocokan dengan tabel R Product Moment $(0,05 ; 28)$ maka didapat nilai $r$ tabel $=0,361$

\section{Uji Validitas}

Tabel 1: Hasil Perhitungan Uji Validitas Variabel X1:Daya Tarik Iklan Layanan Masyarakat

\begin{tabular}{|c|c|c|c|l|}
\hline $\begin{array}{c}\text { Pernyataa } \\
\mathrm{n}\end{array}$ & $\mathrm{R}$ & $>/<$ & $\mathrm{R}$ & \\
Hitung & & Tabel & Keterangan \\
\hline
\end{tabular}




\begin{tabular}{|c|c|c|c|c|}
\hline P 1 & 0.379 & $>$ & 0.361 & Valid \\
\hline P 2 & 0.401 & $>$ & 0.361 & Valid \\
\hline P 3 & 0.399 & $>$ & 0.361 & Valid \\
\hline P 4 & 0.457 & $>$ & 0.361 & Valid \\
\hline P 5 & 0.501 & $>$ & 0.361 & Valid \\
\hline P 6 & 0.487 & $>$ & 0.361 & Valid \\
\hline P 7 & $\mathbf{0 . 2 2 2}$ & $<$ & $\mathbf{0 , 3 6 1}$ & Drop \\
\hline
\end{tabular}

Sumber : Data Olahan SPSS 20

Dalam Tabel diatas menunjukan bahwa dari 7 (tujuh) butir instrument pada variabel (X1): daya Tarik Iklan Layanan Masyarakat didapatkan hasil korelasi positif dengan rentang 0.379-0,501 untuk 6 (enam) butir pernyataan dianggap valid yang ditunjukan oleh nilai koefisien korelasi $r$ lebih besar dari nilai kritisnya 0.361 pada taraf signifikansi 0.05 untuk $n=30$. dan 1 (satu) butir pertanyaan yang didrop dan tidak dapat dilanjutkan ke penelitan selanjutnya.

Tabel 2: Hasil Perhitungan Uji Validitas Variabel X2: Tingkat Pengetahuan

\begin{tabular}{|c|c|c|c|c|}
\hline Pernyataan & $\begin{array}{c}\mathrm{R} \\
\text { Hitung }\end{array}$ & $>/<$ & $\begin{array}{c}\mathrm{R} \\
\text { Tabel }\end{array}$ & Keterangan \\
\hline P 1 & 0,441 & $>$ & 0.361 & Valid \\
\hline P 2 & 0,389 & $>$ & 0.361 & Valid \\
\hline P 3 & $\mathbf{0 , 3 4 0}$ & $<$ & $\mathbf{0 . 3 6 1}$ & Drop \\
\hline P 4 & 0,399 & $>$ & 0.361 & Valid \\
\hline P 5 & 0,513 & $>$ & 0.361 & Valid \\
\hline P 6 & 0,378 & $>$ & 0.361 & Valid \\
\hline P 7 & 0,558 & $>$ & 0.361 & Valid \\
\hline P 8 & $\mathbf{0 , 2 8 9}$ & $<$ & $\mathbf{0 . 3 6 1}$ & Drop \\
\hline P 9 & 0,411 & $>$ & 0.361 & Valid \\
\hline P 10 & $\mathbf{0 , 1 1 2}$ & $<$ & $\mathbf{0 . 3 6 1}$ & Drop \\
\hline P11 & 0,432 & $>$ & 0,361 & Valid \\
\hline P12 & 0,524 & $>$ & 0,361 & Valid \\
\hline
\end{tabular}

Sumber : Data Olahan SPSS 20 
Dalam Tabel diatas menunjukan bahwa dari 12 (dua belas) butir instrument pada variabel X2: Tingkat Pengetahuan, terdapat 9 (sembilan) butir pernyataan yang mempunyai korelasi positif dengan rentang $0.389-0,558$ pernyataan dianggap valid dan terdapat 3 (tiga) butir pernyataan yang nilai koefisien korelasi $\mathrm{r}$ lebih kecil dari nilai kritisnya 0.361 pada taraf signifikansi 0.05 untuk $\mathrm{n}=30$, maka pertanyaan yang didrop dan tidak dapat dilanjutkan ke penelitian selajutnya.

\section{Tabel 3: Hasil Perhitungan Uji Validitas Variabel Y: Keputusan Penggunaan}

\begin{tabular}{|c|c|c|c|c|}
\hline Pernyataan & R Hitung & $>/<$ & R Tabel & Keterangan \\
\hline P 1 & 0,366 & $>$ & 0.361 & Valid \\
\hline P 2 & $\mathbf{0 , 1 9 9}$ & $<$ & $\mathbf{0 . 3 6 1}$ & Drop \\
\hline P 3 & 0,447 & $>$ & 0.361 & Valid \\
\hline P 4 & 0,579 & $>$ & 0.361 & Valid \\
\hline P 5 & 0,663 & $>$ & 0.361 & Valid \\
\hline P 6 & $\mathbf{0 , 2 5 9}$ & $<$ & $\mathbf{0 . 3 6 1}$ & Drop \\
\hline P 7 & 0,588 & $>$ & 0.361 & Valid \\
\hline P 8 & 0,689 & $>$ & 0.361 & Valid \\
\hline P 9 & $\mathbf{0 , 3 1 1}$ & $<$ & $\mathbf{0 . 3 6 1}$ & Drop \\
\hline P 10 & 0,409 & $>$ & 0.361 & Valid \\
\hline P 11 & 0,589 & $>$ & 0.361 & Valid \\
\hline P 12 & 0,701 & $>$ & 0.361 & Valid \\
\hline P 13 & $\mathbf{0 , 2 4 8}$ & $<$ & $\mathbf{0 , 3 6 1}$ & Drop \\
\hline P14 & 0,772 & $>$ & 0,361 & Valid \\
\hline P15 & 0,468 & $>$ & 0,361 & Valid \\
\hline
\end{tabular}

Dalam Tabel diatas menunjukan bahwa dari 15 (limabelas) butir instrument pada variabel Keputusan penggunaan, terdapat 12 (dua belas) butir pernyataab korelasi positif dengan rentang 0.366 - 0,772 untuk 12 (duabelas) butir pernyataan dianggap valid yang ditunjukan oleh nilai koefisien korelasi $r$ lebih besar dari nilai kritisnya 0.361 pada taraf signifikansi 0.05 untuk $n=30$, maka tidak ada butir pertanyaan yang didrop dan tidak dapat dilanjutkan ke penelitian selanjutnya. 


\section{Uji Reabilitas}

Tabel 4: Uji Reabilitas

Variabel X1: Daya Tarik Iklan Layanan Masyarakat

\begin{tabular}{|r|r|r|}
\hline $\begin{array}{c}\text { Cronbach's } \\
\text { Alpha }\end{array}$ & $\begin{array}{c}\text { Cronbach's Alpha } \\
\text { Based on Standardized } \\
\text { Items }\end{array}$ & $\begin{array}{c}\text { N } \\
\text { of Items }\end{array}$ \\
\hline .913 & .959 & 7 \\
\hline
\end{tabular}

Sumber : Data Olahan SPSS 20

Dari hasil analisis tabel diatas, diperoleh koefisien reliabilitas Alpha Cronbach sebesar 0.913 dengan hasil tersebut maka bisa dikatakan bahwa data tersebut adalah reliabel, dengan angka menunjukan mendekati angka 1.

Tabel 5: Uji Reabilitas

Variabel Kualitas Pelayanan

\begin{tabular}{|r|r|r|}
\hline $\begin{array}{c}\text { Cronbach's } \\
\text { Alpha }\end{array}$ & $\begin{array}{c}\text { Cronbach's Alpha } \\
\text { Based on Standardized } \\
\text { Items }\end{array}$ & \multicolumn{1}{|c|}{$\begin{array}{c}\text { N } \\
\text { of Items }\end{array}$} \\
\hline .899 & .924 & 10 \\
\hline
\end{tabular}

Sumber : Data Olahan SPSS 20

Dari hasil analisis tabel diatas, diperoleh koefisien reliabilitas Alpha Cronbach sebesar 0.899 dengan hasil tersebut maka bisa dikatakan bahwa data tersebut adalah reliabel, dengan angka menunjukan mendekati angka 1.

Tabel 6: Uji Reabilitas Variabel Kepuasan Pasien

\begin{tabular}{|r|r|r|}
\hline $\begin{array}{c}\text { Cronbach's } \\
\text { Alpha }\end{array}$ & $\begin{array}{c}\text { Cronbach's Alpha Based } \\
\text { on Standardized Items }\end{array}$ & \multicolumn{2}{|c|}{$\begin{array}{c}\text { N } \\
\text { of Items }\end{array}$} \\
\hline .829 & .924 & 15 \\
\hline
\end{tabular}

Sumber : Data Olahan SPSS 20

Dari hasil analisis tabel diatas, diperoleh koefisien reliabilitas Alpha Cronbach sebesar 0.829 dengan hasil tersebut maka bisa dikatakan bahwa data tersebut adalah reliabel, dengan angka menunjukan mendekati angka. 


\section{Hasil Uji Heteroskedastisitas}

Uji heteroskedastisitas bertujuan untuk menguji apakah dalam sebuah regresi terjadi ketidaksamaan varians residual dari satu pengamatan ke pengamatan lain. Model regresi yang baik apabila terjadi homoskedastisitas dalam modelnya. Metode pengujian uji heteroskedastisitas adalah dengan melihat titiktitik pada grafik Scatterplot. Jika titik-titik pada grafik Scatterplot menyebar secara merata tanpa membentuk pola tertentu maka terjadi homoskedastisitas, namun apabila titik-titik grafik Scatterplot membentuk pola tertentu maka terjadi heteroskedastisitas. Berikut adalah hasil uji heteroskedastisitas yang didapatkan oleh peneliti:

Tabel 7: Uji Heteroskedastisitas

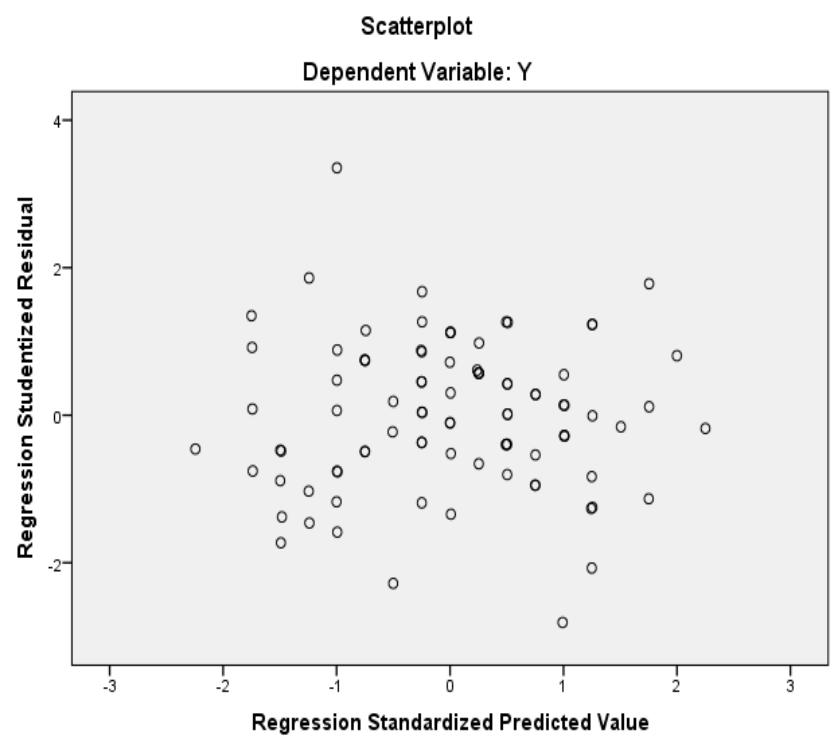

Dari gambar di atas dapat dilihat bahwa titik-titik pada grafik Scatterplot menyebar secara merata dan tidak membentuk pola tertentu yang jelas, maka dapat disimpulkan tidak terjadi heteroskedastisitas.

\section{Uji Korelasi}

Tabel 8: Uji Korelasi

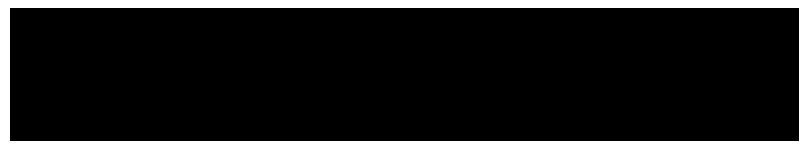

a. Predaktor : (Constanta) X1 X2

b. Dependen Variabel : Y 
Tabel diatas menunjukan bahwa nilai koefisien korelasi yaitu sebesar 0,684. Nilai ini menunjukan bahwa variabel X1: Daya tarik iklan layanan masyarakat tentang Vaksin MR dan variabel X2: Tingkat Pengetahuan memiliki hubungan yang kuat dengan variabel Y: Keputusan penggunaan vaksin MR.

\section{Uji Determinasi}

Analisis Koefisien Determinasi $\left(\mathrm{R}^{2}\right)$ digunakan untuk mengetahui seberapa besar presentase sumbangan pengaruh variabel independen terhadap variabel dependen baik secara parsial maupun stimultan. Hal ini dapat dilihat pada kolom R Square.

\section{Tabel 9: Model Summary}

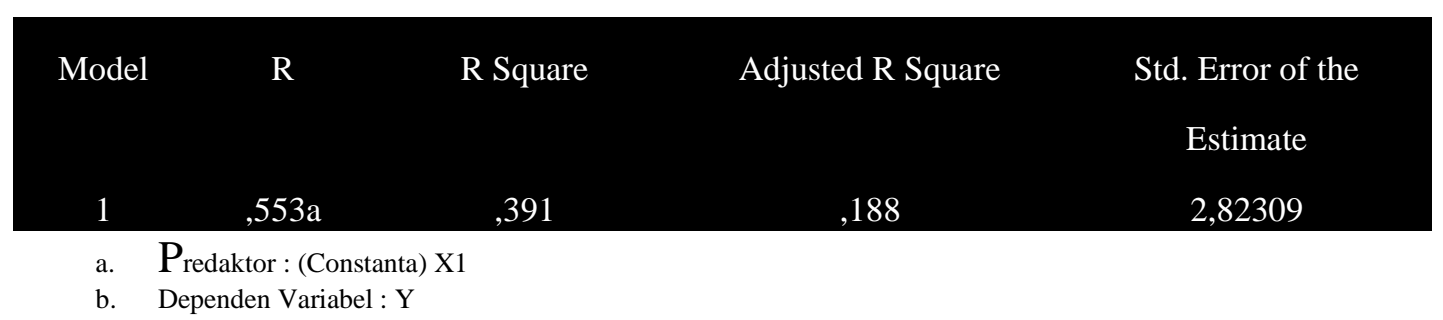

Berdasarkan tabel diatas, hasil R Square untuk variabel X1: Daya tarik iklan layanan masyarakat tentang vaksin MR di Youtube sebesar 0,391. Hal ini menunjukan bahwa variabel X1: daya tarik iklan layanan masyarakat vaksin MR memiliki kontribusi terhadap variabel Y: Keputusan penggunaan vaksin MR sebesar $0,391 \times 100 \%=39,1 \%$. Hal ini berarti daya tarik iklan layanan masyarakat vaksin MR di Youtube hanya memberikan kontribusi sebesar 39,1\% terhadap keputusan penggunaan vaksin MR. Sisanya sebesar 60,9\% dipengaruhi oleh faktor-faktor lainnya.

Tabel 10: Model Summary

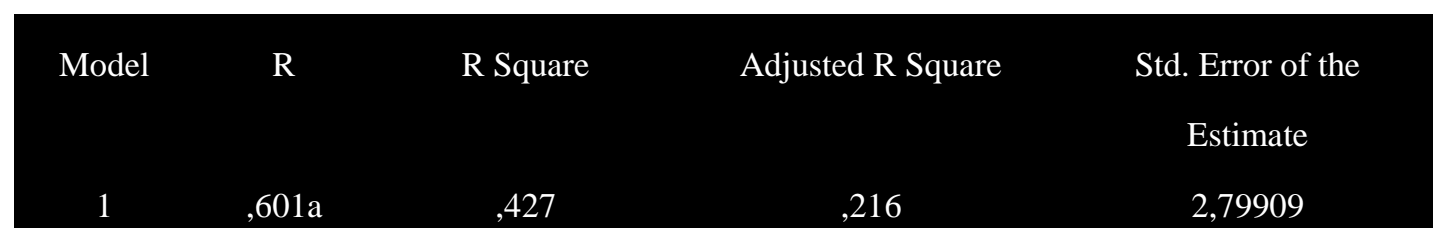


a. Predaktor : (Constanta) X2

b. Dependen Variabel : Y

Berdasarkan tabel di atas, hasil $\mathrm{R}$ Square untuk variabel X2: Tingkat pengetahuan sebesar 0,427. Hal ini menunjukan bahwa Tingkat Pengetahuan memiliki kontribusi terhadap keputusan penggunaan vaksin MR sebesar 0,427 x $100 \%=42,7 \%$. Hal ini berarti tingkat pengetahuan memberikan kontribusi sebesar42,7\% terhadap keputusan penggunaan vaksin MR. Sisanya sebesar 57,3\% dipengaruhi oleh faktor-faktor lainnya.

\section{Tabel 11: Model Summary}

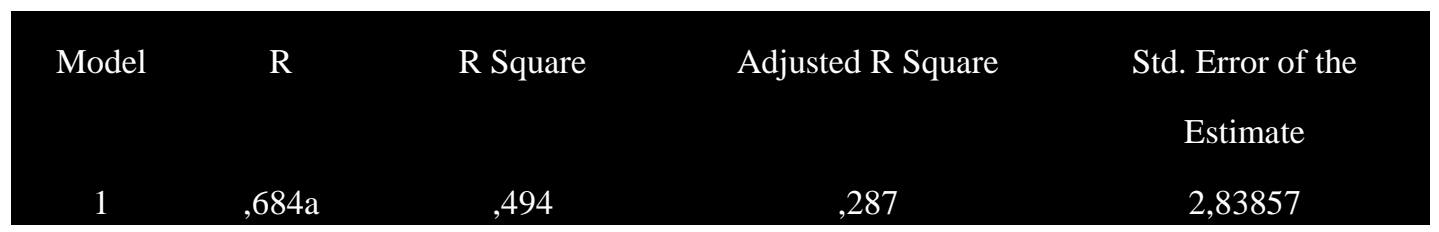

a. Predaktor : (Constanta) X1 X2

b. Dependen Variabel : Y

Berdasarkan tabel di atas, hasil R Square untuk variabel X1: daya tarik iklan layanan masyarakat dan variabel X2: tingkat pengetahuan sebesar 0,494. Hal ini menunjukan bahwa variabel daya tarik iklan layanan masyarakat vaksin MR diyoutube dan variabel tingkat pengetahuan secara bersama-sama (stimultan) memiliki kontribusi terhadap variabel keputusan penggunaan sebesar 0,494 $\mathrm{x}$ $100 \%=49,4 \%$. Hal ini berarti daya tarik iklan layanan masyarakat vaksin MR di Youtube dan tingkat pengetahuan memberikan kontribusi secara bersamaan terhadap keputusan penggunaan vaksin MR sebesar 49,4\%, sedangkan sisanya50,6\% dipengaruhi oleh faktor-faktor lainnya.

\section{Uji Regresi Linier Berganda}

Berdasarkan perhitungan regresi berganda antara daya tarik iklan layanan masyarakat dan tingkat pengetahuan terhadap keputusan menggunakan dengan menggunakan SPSS 20, hasil yang didapatkan peneliti adalah sebagai berikut: 


\section{Tabel 12: Regresi Linier Berganda}

\begin{tabular}{cccccccr} 
& \multicolumn{2}{c}{ Unstandardized } & \multicolumn{2}{c}{ Standardized } & & \multicolumn{3}{c}{ Collinearity } \\
Model & \multicolumn{2}{c}{ Coefficients } & Coefficients & & \multicolumn{3}{c}{ Statistic } \\
& B & Std.Error & Beta & T & Sig. & Tolerance & VIF \\
1 & 16,826 & 4,972 & & 3,659 &, 001 & & \\
(Constant) &, 445 & .197 &, 448 & $3,, 685$ &, 002 &, 978 & 1,257 \\
X1 &, 498 &, 198 &, 479 & 3,917 &, 001 & .978 & 1,257 \\
X2 & & & & & & & \\
\hline
\end{tabular}

Dari hasil perhitungan tabel tersebut maka dapat dibentuk persamaan regresi berganda sebagai berikut:

$$
\mathrm{Y}=16,826+0,445 \mathrm{X} 1+0.498 \mathrm{X} 2
$$

Dimana :

Y : Keputusan Penggunaan Vaksin MR

X1 : Daya Tarik Iklan Layanan Masyarakat MR di Youtube

X2 : Tingkat Pengetahuan

a. Tabel tersebut menunjukan bahwa nilai constanta pada persamaan regresi adalah 16.826. Koefisien variabel X1 Daya tarik iklan layanan masyarakat signifikan dalam model regresi dengan nilai koefisien rergresi sebesar 0,445. tanda positif pada nilai koefisien tersebut menunjukan hubungan searah antara daya tarik iklan layanan masyarakat vaksin MR dengan keputusan penggunaan vaksin MR dimana secara statistik memiliki arti apabila variabel daya tarik iklan layanan masyarakat vaksin MR naik satu-satuan maka variabel Keputusan penggunaan vaksin MR akan mengalami kenaikan sebesar 0,445.

b. Koefisien variabel X2 Tingkat pengetahuan signifikan dalam model regresi dengan nilai koefisien regresi variabelnya sebesar 0.498 . Tanda positif pada nilai koefisien tersebut menunjukan hubungan searah antara tingkat pengetahuan dengan keputusan penggunaan vaksin MR dimana secara statistik memiliki arti apa bila variabel tingkat pengetahuan naik satu-satuan maka variabel keputusan penggunaan vaksin MR akan mengalami kenaikan sebesar 0,498 . 


\section{Uji Parsial (Uji T)}

Uji t dilakukan untuk mengetahui tingkat signifikansi atau setidaknya pengaruh dari masing-masing variabel independen terhadap variabel dependen. Hasil yang didapatkan peneliti adalah sebagai berikut:

\section{Tabel 13: Uji T}

\begin{tabular}{|c|c|c|c|c|c|c|c|}
\hline \multirow[t]{2}{*}{ Model } & \multicolumn{2}{|c|}{$\begin{array}{c}\text { Unstandardized } \\
\text { Coefficients }\end{array}$} & \multirow{2}{*}{$\begin{array}{c}\text { Standardized } \\
\text { Coefficients } \\
\text { Beta }\end{array}$} & & & \multicolumn{2}{|c|}{ Collinearity Statistic } \\
\hline & B & Std.Error & & $\mathrm{T}$ & Sig. & Tolerance & VIF \\
\hline 1 & 16,826 & 4,972 & & 3,659 & ,001 & & \\
\hline (Constant) & ,445 & .197 & 448 & 3,685 & ,002 & ,978 & 1,257 \\
\hline $\begin{array}{l}\mathrm{X} 1 \\
\mathrm{X} 2\end{array}$ & ,498 & , 198 & ,479 & 3,917 & 001 & .978 & 1,257 \\
\hline
\end{tabular}

a. Dependen variabel : $\mathrm{Y}$

b. Predictor (constanta): X1 X2

Berdasarkan pada tabel tersebut maka dilakukan langkah-langkah uji t adalah:

a. Nilai hitung untuk variabel X1 daya tarik iklan layanan masyarakat sebesar 3,685> t tabel 1.662 dan signifikansi (Sig) 0,002<0,05 Maka dapat disimpulkan bahwa $\mathrm{H} 0$ ditolak dan Ha diterima yang artinya "Daya tarik iklan layanan masyarakat vaksin MR berpengaruh positif terhadap keputusan penggunaan vaksin MR.

b. Nilai hitung untuk X2 sebesar 3,917 > t tabel 1.662 dan signifikan (Sig) 0,002 $<0,05$. Maka dapat disimpulkan bahwa H0 ditolak dan Ha diterima yang artinya "tingkat pengetahuan berpengaruh positif terhadap keputusan penggunaan vaksin MR".

\section{Uji Stimultan (Uji F)}

Uji F dilakukan untuk mengetahui tingkat signifikansi pengaruh variabelvariabel independen secara bersama-sama terhadap variabel dependen. Hasil yang didapatkan peneliti adalah sebagai berikut:

\section{Tabel 14: Uji F}




\begin{tabular}{cccccc}
1 & & & & & \\
Regression & 180.269 & 2 & 91.479 & 15.768 &, $000 \mathrm{~b}$ \\
Residual & 656.239 & 88 & 6.846 & & \\
Total & 789.672 & 90 & & & \\
\hline
\end{tabular}

a. Dependen variabel : Y

b. Predictor (constanta): X1 X2

Pada uji ini didapati F hitung sebesar 15.768> dari F tabel yaitu 3.099 dan nilai Signifikasi (Sig) $0,000<0,05$. Dapat disimpulkan bahwa pada model ini terdapat pengaruh secara simultan antara daya tarik iklan layanan masyarakat vaksin MR dan tingkat pengetahuan terhadap keputusan penggunaan vaksin MR.

Teknologi informasi dan komunikasi dipahami sebagai piranti yang perlu dipergunakan secara bertanggung-jawab. Kesadaran bahwa teknologi ini membawa perubahan perilaku, pola interaksi secara personal karena dapat dipergunakan berkali-kali, kapan saja dan dimana saja. Temuan teknologi informasi dan komunikasi mempertegas pemanfaatan teknologi ditentukan oleh kematangan kepribadian seseorang. Sedangkan kematangan kepribadian seseorang ditentukan oleh kontruksi konsep dan identitas diri, sehingga teknologi informasi dan komunikasi pada dasarnya dapat menambah bagi personal yang mempergunakannya.

Menurut Spitzberg dalam Greiffenstern (2010) CMC adalah termasuk kepada interaksi manusia yang dilakukan dan di fasilitasi melalui teknologi berbasis digital. Pertukaran pesan menggunakan media baru bersifat segera (sinkronitas), jika dikaitkan dengan penelitian ini bahwa iklan layanan masyarakat yang diakses oleh pengguna melalui youtube pertukaran pesannya bersifat segera, dimana pengguna yang ingin berinteraksi secara langsung tentang iklan tersebut dapat ditanganin langsung oleh pihak yang berkompeten sehingga keingin tahuan pengguna dapat terjawab dengan segera. Komunikasi yang berlangsung bersifat komunikasi dua arah yang memungkinkan terjadinya komunikasi yang berkelanjutan.

Iklan Layanan Masyarakat tentang vaksin MR membujuk masyarakat dengan cara mengajak dan menghimbau masyarakat untuk mengerti, menyadari, dan memikirkan agar tidak terjerumus dengan permasalahan yang seharusnya dapat diatasi melalui pemberian vaksin MR. Di negara-negara maju iklan telah 
dirasakan manfaatnya dalam menggerakkan solidaritas masyarakat dalam menghadapi suatu masalah sosial. Dalam iklan layanan masyarakat tersebut disampaikan pesan sosial yang bermaksud untuk membangkitkan kepedulian pengguna terhadap masalah yang mengancam kesehatan generasi bangsa.

Iklan vaksin MR ini bertujuan meberikan informasi yang akurat untuk masyarakat dalam rangka mengajak masyarakat untuk berpartisipasi serta berpikiran positif terhadapat iklan yang ditayangkan diberbagai media cetak, elektronik maupun media online ini untuk menghimbau, mengingatkan dan mengajak masyarakat untuk tergerak melakukan hal demi terwujudnya keserasian bersama dalam masyarakat. Berbagai penjelasan komunikator berkompeten hadir untuk memberikan informasi kepada masyarakat.

Melalui iklan layanan masyarakat vaksin MR menambah pengetahuan masyarakat tentang pentingnya vaksin MR untuk anak-anak, melalui gerakan pemberian vaksin MR ini secara menyeluruh dan kampanye kesehatan yang terus digencarkan face to face dan media komunikasi diharapkan Indonesia dapat terbebaskan dari penyakit Rubella dimasa yang akan datang. Penerimaan informasi dalam iklan layanan masyarakat sangat penting dimata masyarakat. Dimana setiap daerah yang ada di Indonesia memiliki budaya dan kebiasaan yang berbeda-beda.

Ada banyak peraturan beriklan di Indonesia yang memiliki permasalahan keberagaman budaya, agama, bahasa, gaya hidup dan penilaian dari masingmasing kelompok masyaraat. Pemberian vaksin MR ini menuai pro dan kontra bagi pengguna, ada yang berpikiran bahwa bertentangan dengan agama yang dianut. Melalui iklan layanan masyarakat ini memberikan informasi yang dilengkapi penjelasan dari pemuka agama yang mengatakan vaksin MR ini wajib dan dibenarkan oleh agama.

Diharapkan melalui iklan layanan masyarakat ini masyarakat mendapatkan informasi menambah pengetahuan mereka tentang pentingnya vaksin MR ini. Melalui iklan layanan masyarakat ini pengguna jadi tertarik dan mengambil keputusan untuk menggunakan vaksin MR ini. Jika dikaitkan dengan hasil 
penelitian ini bahwa tingkat hubungan antara daya tarik iklan layanan masyarakat dan tingkat pengetahuan masyarakat terhadap keputusan penggunaan vaksin MR.

\section{SIMPULAN}

Daya tarik iklan layanan masyarakat memiliki hubungan positif dan sedang dengan keputusan penggunaan vaksin MR sebesar 0,391 atau 39,1\% . Tingkat pengetahuan memiliki hubungan positif dan sedang dengan keputusan penggunaan vaksin MR sebesar 0,427 atau 42,7\%. Daya tarik iklan layanan masyarakat dan tingkat pengetahuan memiliki hubungan yang positif dan sedang dengan keputusan penggunaanvaksin MR sebesar 0,494 atau 49,4\%.

Nilai t hitung variabel daya tarik iklan layanan masyarakat sebesar 3,685> t tabel 1.662 Maka dapat disimpulkan bahwa H0 ditolak dan Ha diterima yang artinya "Daya tarik iklan layanan masyarakat vaksin MR berpengaruh positif terhadap keputusan penggunaan vaksin MR. Nilai $t$ hitung untuk tingkat pengetahuan sebesar 3,917 > t tabel 1.662. Maka dapat disimpulkan bahwa H0 ditolak dan Ha diterima yang artinya "tingkat pengetahuan berpengaruh positif terhadap keputusan penggunaan vaksin MR". Pada uji F didapatkan hasil sebesar 15.768 sedangkan $\mathrm{F}$ tabel sebesar 3,099. Maka F hitung > dari F tabel yaitu $15.768>3.099$, dapat disimpulkan bahwa terdapat pengaruh secara simultan daya tarik iklan layanan masyarakat vaksin MR dan tingkat pengetahuan terhadap keputusan penggunaan vaksin MR.

\section{DAFTAR PUSTAKA}

Aini, Mila Setiawati Yulfita. Aida Welven. 2015. Pegaruh Media Sosial Terhadap Minat Beli Konsumen (Studi Kasus Mahasiswa Manajemen Universitas Pasir Pangaraian. Skripsi Program Studi Manajemen. Fakultas Ekonomi. Universitas Pasir Pangaraian.

Bagdikian, BenH. 2004. The New Media Monopoly. Boston: Beacon Press.

Cahyono, Eko. Budiardjo, Hardman. Hidayat, Wahyu. 2016. Perancangan Video Iklan Layanan Masyarakat Alat Kontrasepsi Berbasis Online Sebagai Sarana Informasi Program Keluarga Berencana Institut Bisnis Dan Informatika STIKOM Surabaya. Vol 5, No.2, Art Nouveau.

Greiffenstern, S. 2010. The influence of computers, the internet and computermediated communication on everyday English. Berlin: Logos-Verl. 
Kriyantono, Rachmat. 2012. Teknik Praktis Riset Komunikasi. Jakarta: Kencana Prenada Media Group.

Kriyantono, Rachmat. 2008. Public Relations Writing. Jakarta: Kencana Prenada Media Group.

McQuail, Denis. 2000. Mass Communication Theory. London: Sage Publication.

Mowen, John C, and Minor Michael. 2002. Perilaku Konsumen Jilid 1, Edisi Kelima. Jakarta: Penerbit Erlangga.

Pujiyanto. 2013. Iklan Layanan Masyarakat. Yogyakarta: Penerbit ANDI.

Saragih, Hoga dan Ramdhany, Rizky, 2012. JURNAL. Pengaruh Intensi Pelanggan Dalam Berbelanja Online Kembali Melalui Media Teknologi Informasi Forum Jual Beli (FJB) Kaskus. Jakarta: Universitas Bakrie.

Sugiyono. 2008. Metode Penelitian Kuantitatif, Kualitatif dan R\&D. Bandung: Penerbit Alfabeta.

Sugiyono. (2015), Statistika untuk Penelitian. Bandung : C.V Alfabeta.

Suyanto M. 2005. Strategi Perencanaan Iklan Televisi. Yogyakarta: Liberty.

Wood, Andrew F and Smith, Matthew J. 2005. Online Communication, Lawrence Erlbaum Associates Publishers, New Jersey.

Yuniyanto, Herdian Rizky. 2018. Pengaruh Iklan terhadap Minat Beli Pengguna Youtube dengan Brand Recognition sebagai Variabel Intervening http://journal.uinjkt.ac.id/index.php/esensi DOI: 10.15408/ess.v8i1.5885. Vol. 8, No.1, 2018 (hal 21-28) Jurnal Bisnis dan Manajemen.

BULETIN APJII EDISI 22 - Maret 2018 